THESIS APPROVAL SHEET

\title{
WAKING LIFE
}

\section{A Thesis Presented}

by

Dionne Irving

Approved:
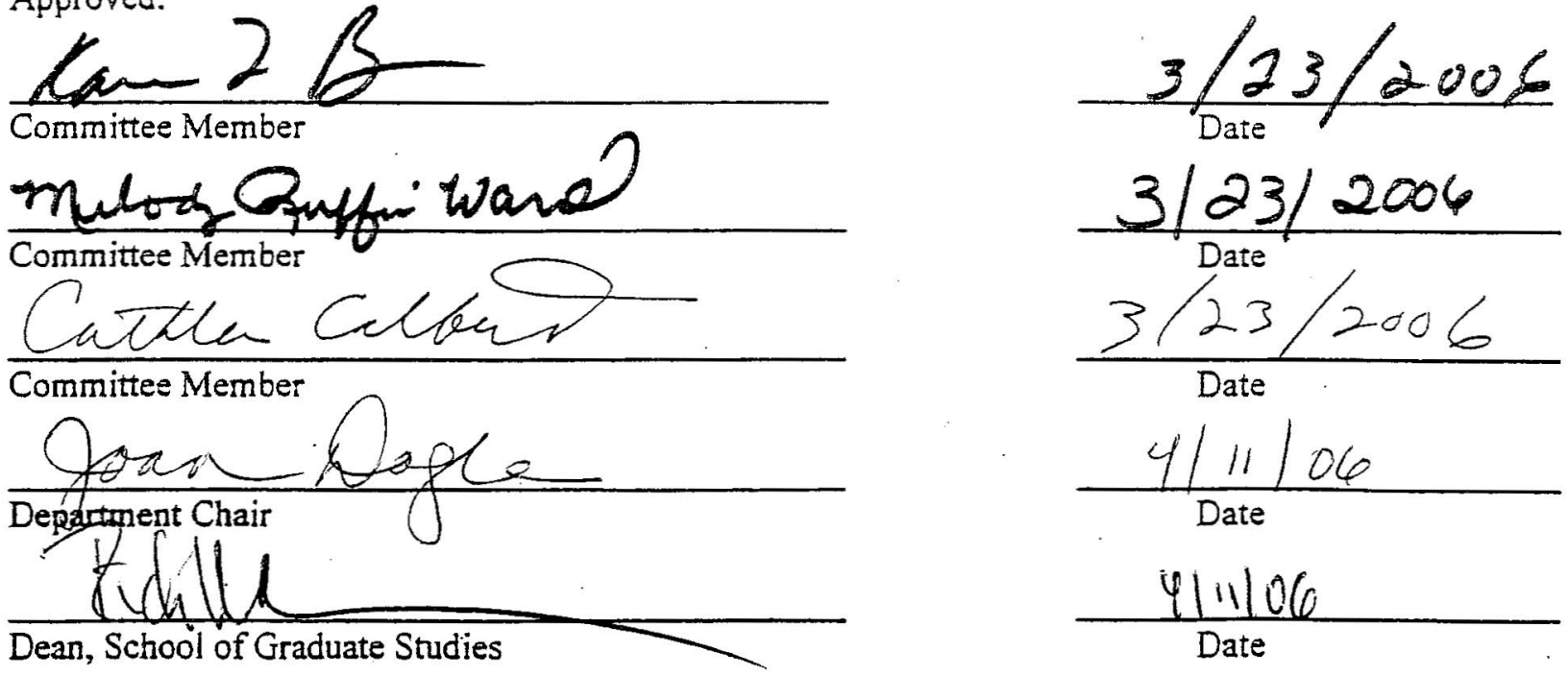